\title{
Orientalisme Romantis: Imajinasi Tentang Timur Sebelum Edward Said
}

\author{
Gumillar Irfanullah \\ Universitas Indonesia \\ gumilarirfanullah@gmail.com
}

\begin{abstract}
Orientalism is a 1978 book by Edward W. Said, in which Said studies the cultural representations that are the bases of Orientalism, the West's patronizing perceptions and fictional depictions of "The East" - the societies and peoples who inhabit the places of Asia, North Africa, and the Middle East. Orientalism, the Western scholarship about the Eastern World, was and remains inextricably tied to the imperialist societies who produced it, which makes much Orientalist work inherently political and servile to power, and thus intellectually suspect.

Orientalism is the exaggeration of difference, the presumption of Western superiority, and the application of clichéd analytical models for perceiving the Oriental world. As such, Orientalism is the source of the inaccurate, cultural representations that are the foundations of Western thought and perception of the Eastern world, specifically about the region of the Middle East. The principal characteristic of Orientalism is a "subtle and persistent Eurocentric prejudice against Arab-Islamic peoples and their culture", which prejudice derives from Western images of what is Oriental (cultural representations) that reduce the Orient to the fictional essences of "Oriental peoples" and "the places of the Orient"; such cultural representations dominate the communications (discourse) of Western peoples with non-Western peoples. Orientalism proposes that much of the Western study of Islamic civilization was an exercise in political intellectualism; a psychological exercise in the self-affirmation of "European identity"; not an objective exercise of intellectual enquiry and the academic study of Eastern cultures. Therefore, Orientalism was a method of practical and cultural discrimination that was applied to non-European societies and peoples in order to establish European imperial domination.
\end{abstract}

Keywords: Orientalism, The East, Eastern World 


\section{A. Pendahuluan}

Ketika Edward Said menulis bukunya yang fenomenal, Orientalism (terbit tahun 1978), dunia memiliki pandangan yang berbeda terhadap sejarah yang mengiringi kolonialisme-imperialisme Barat atas negara-negara jajahannya. Buku Said membuat dunia terbelalak bahwa ada motif-motif intelektual yang sengaja mendudukkan Timur sebagai subyek yang bisa ditafsirkan, dianalisis, dan digambarkan begitu rupa tanpa acuh terhadap pandangan orang-orang Timur itu sendiri terhadap diri mereka. Said menggagas lembaran baru pada beberapa disiplin keilmuan terutama yang berkaitan dengan studi-studi Timur Tengah baik dari sisi sejarahnya, antropologi, sosiologi, studi kawasan dan perbandingan agama. Bagi Said, orientalisme menyiapkan semacam rasionalisasi bagi kolonialisme Barat yang memandang Timur sebagai subyek inferior serta tertinggal dan harus melibatkan Barat untuk dilakukan "penyelamatan".

Ketertarikan sarjana Barat terhadap Timur lebih didominasi sikap yang tidak simpatik, mereka mengkaji Timur sebagai the other, penuh stereotip-stereotip rasial, ideologis dan imperialis. Edward Said menganggap kegagalan orientalisme masa kolonial sebagai kegagalan intelektual dan juga kegagalan kemanusiaan. Orientalisme, bagi Said adalah pengingat akan degradasi yang menyeleweng dari ilmu pengetahuan, apapun bentuknya ${ }^{1}$.

Dalam pemahaman Said, orientalisme merupakan struktur ide dan pemikiran yang terorganisir, semacam pola untuk membuat generalisasi tertentu tentang belahan dunia lain yang disebut-sebut sebagai "Timur". Artinya, Said meyakini bahwa ada otoritas epistemologis dan dorongan intelektual yang mengantarkan Barat menginjakkan kaki imperialismenya di negara-negara Timur. Singkatnya, demikian Said, orientalisme telah berhasil menjadi suatu jaringan kepentingan yang secara tak terelakkan selalu dikatikan dengan entitas tertentu, “dunia Timur," sebagai pokok kajiannya ${ }^{2}$. Terminologi orientalisme yang digagas Said ini menantang definisi Barat terhadap orientalisme itu sendiri. Orientalisme mengesankan ada perbedaan yang fundamental antara Timur dan Barat; bahwa Timur (orient) adalah bagian belahan bumi dan manusia-manusia yang tidak beradab, sedangkan Barat (occident) berkebalikan daripadanya, yaitu sebuah wilayah bagian dunia yang memiliki peradaban.

\footnotetext{
${ }^{1}$ Orientalism: The Romantic's Added Dimension; or Edward Said Refuted, artikel oleh Naji B. Oueijan (Universitas Notre Dame, Zouk Mikayel, Lebanon. 2010), hlm.514.

${ }^{2}$ Orientalism: The Romantic's Added Dimension; or Edward Said Refuted, artikel oleh Naji B. Oueijan (Universitas Notre Dame, Zouk Mikayel, Lebanon.2010), hlm. 4.
} 
Orientalisme digunakan untuk mendefinisikan "siapa mereka". Permasalahan utama yang ditimbulkan dari orintalisme, barangkali dalam pengamatan Said, adalah ketika Barat mulai menggeneralisasi asumsi-asumsi mereka tentang Timur, lalu menggambarkan karakteristik "buatan" tentang Timur itu ke dalam dunia Barat melalui laporan-laporan yang bersifat ilmiah, karya sastra, dan sumber-sumber lainnya. Pandangan Barat yang sepihak terhadap Timur ini ditakutkan membuat bangsa Barat memiliki sikap antagonistik terhadap Timur. Dan ini barangkali apa yang ingin diungkap oleh Said melalui bukunya tersebut, bahwa ada stereotip-stereotip negatif yang dihasilkan pembacaan Barat terhadap Timur. Dampak paling radikal barangkali akan berimbas kepada agama yang mendominasi di belahan bumi Timur Tengah, Islam, yang dilihat sebagai agama teroris, barbar, dan memiliki penganut yang tidak beradab.

Said memang membuat dunia tahu bahwa klaim-klaim ilmiah dibalik studi tentang Timur menyembunyikan agenda-agenda politis yang destruktif yang menghantarkan Eropa menjajah dunia-dunia Timur. Ilmu pengetahuan dijadikan alat untuk menjustifikasi, memberikan informasi dan memetakan Timur begitu rupa untuk kepentingan Barat. Orientalisme dipandang sebagai sisi buruk dan kelam bagi dunia intelektual dan gerakan ilmiah, menjadi pengingat bahwa ada sistem-sistem pemikiran dan wacana kekuasaan yang sengaja diterapkan, mungkin tidak saja hanya dulu, tapi juga sekarang dan di masa depan.

Apabila orintalisme dipandang sebagai kedok intelektual untuk mendukung kolonalisme-imperialisme Barat, lalu bagaimana dengan interaksi Barat dengan Timur sebelum yang digambarkan Said. Seperti apa citra Timur di hadapan Barat sebelum, katakanlah, gelombang penjajahan mulai meminjam ilmu-ilmu ketimuran untuk mendukung agendanya. Artinya, ada semacam tranformasi terminologis yang melekat pada kata-kata "orientalisme" sepanjang sejarah hubungan Barat dengan Timur. Sebelum citra antagonistik yang digambarkan Said pada orientalisme, apa makna "orientalisme" itu sendiri sebelumnya? Tulisan ini berusaha menelusuri definisi orientalisme sebelum Said serta menguak tranformasinya dari waktu ke waktu.

\section{B. Orientalisme: Akar dan Fungsi Terminologis}

Dalam telaah Ivan Davidson ${ }^{3}$, terma “orientalisme” dalam bahasa Inggris muncul pada tulisan kritikus sastra abad 18 Joseph Spencer. Pada essainya yang diterbitkan tahun 1726, Essay on Pope's Odyssey, Spencer menyebut "orientalisme" sebagai "dunia baru".

3 . Kalmar, Ivan. Early Orientalism Imagined Islam and The Notion of Sublime Power (New York: Routledge, 2012), hlm.19. 
Spencer berkata ketika mengomentari Homerus: "Sekarang kamu ulangi dalam bahasa Inggris. Nampaknya aku ingin sesuatu yang menyenangkanku, di mana orang-orang Yunani berkata "Ketika matahari binasa keluar dari surga, dan ketika kegelapan terburuburu menutupi bumi!'” aku tidak bisa mengungkapkan keutuhan kata-kata tersebut, tetapi kamu akan tahu aslinya; dan, aku takut, kamu tidak akan pernah lagi menemukan terjemahan yang menyamainya. Seluruh penglihatan prophetik itu, ialah sebenarbenarnya ketundukan, dan pada dasarnya, memberi kita Orientalisme tertinggi dari apa yang kita temui dalam bagian tulisan-tulisan Homer yang lain."sikap Spencer terhadap Homerus terkesan simpatik dan menampilkan admiration atau kekaguman atas "kepatuhan yang sejati” dari Orient (Timur).

Dalam pengamatannya, Ivan meyakini bahwa kekaguman tersebut menjadi karakteristik orientalisme sebelum nantinya terjadi pergeseran makna pada masa imperialisme yang diteriakkan oleh Said. Dalam tilikan Said, orientalisme sudah bergeser dari yang asalnya hanya berupa kekaguman, menjadi semacam gaya Barat untuk mendominasi, menstrukturisasi, dan menancapkan otoritasnya atas Timur. Apa yang ingin digagas oleh Ivan, sebagaimana ia kutip dari Zachari Lockman, bahwa orientalisme sendiri memiliki tidak bisa dipahami dan dicirikan oleh satu pandangan, tetapi beberapa pandangan tentang Timur Tengah ${ }^{4}$.

Cara pandang Barat yang dicirikan oleh kekaguman terhadap Timur sebagai inspirasi spiritual menjadi bukti dalam pendekatan Barat terhadap Timur, terutama pada tulisan-tulisan pra-romantisisme di Inggris yang membaca Kitab Suci sebagai dokumen Timur. Kajian-kajian biblikal pada masa ini membuka gerbang kajian kritik kitab suci yang mempengaruhi belantika dunia akademik Barat.

Apa yang disebut Ivan sebagai soft orientalism ini terdapat pada gagasan-gagasan dan pandangan penulis seperti Wolfgang Goethe yang oleh Edward Said sendiri disebut sebagai contoh orang yang mampu melampaui prasangka anti-oriental ${ }^{5}$. Sebelum dijadikan tujuan dan pendorong imperialisme, orientalisme merupakan semacam fakta budaya; fenomena kebudayaan yang disajikan oleh kajian-kajian dan penelitian yang dilakukan Barat untuk mengetahui seluk beluk Timur.

${ }^{4}$ Kalmar, Ivan. Early Orientalism Imagined Islam and The Notion of Sublime Power (New York: Routledge, 2012), hlm.5.

${ }^{5}$ Kalmar, Ivan. Early Orientalism Imagined Islam and The Notion of Sublime Power (New York: Routledge, 2012), hlm.6. 
Orientalisme pra-kolonialisasi lebih didominasi oleh geliat ketertarikan, baik simpatik ataupun tidak simpatik, terhadap Timur dan Barat melalui kajian bahasa-bahasa Timur, seni, adat kebiasaan dan keyakinan untuk menemukan fase pemikiran manusia dan mempertemukan ikatan antara dua kebudayaan Timur dan Barat. Orientalisme di sini digunakan sebagai istilah yang maknanya lebih umum, tujuannya lebih didominasi oleh keingintahuan terhadap budaya Timur. Bisa dikatakan bahwa ide orientalisme mula-mula ialah mengetahui orang lain melalui upaya serius guna menemukan pengetahuan atas jiwa peradaban-peradaban, serta mengungkap filsafat budaya-budaya Timur. Tujuan awal ini bisa jadi menjadi faktor utama orientalisme untuk mengetahui dunia islam, pemikiran dan budayanya ${ }^{6}$.

Ketertarikan akan pengetahuan dan kekayaan budaya yang dimiliki Timur inilah yang mendorong para sarjana Barat untuk mengkaji orient (Timur). Ketertarikan ini bahkan melahirkan beberapa pemikir ke-Timur-an yang melahirkan karya-karya dan penemuan yang mencengangkan.

Pada akhir abad ke-18, sarjana-sarjana Prancis dan Inggris mulai mempelajari bahasa Sanskerta dari sarjana India. Bahasa Sanskerta merupakan bahasa agama Hindu yang masih hidup sampai saat itu. Tidak lama, penerjemahan beberapa bagian literatur klasik Persia bermunculan. Pada tahun 1829, Jean-Francois Champollion (1790-1832) dan beberapa sarjana lainnya mulai memecahkan aksara hieroglyph yang menjadi tulisan Mesir kuno. Upaya Champollion mampu membuka pintu kajian ilmiah tentang peradaban Mesir. Di Barat, pusat-pusat studi Timur mulai dibangun, sebut saja A School of Living Oriental Languages yang didirikan di Paris pada tahun 1795. Bahasa arab yang diajarkan oleh orientalis Silverstre de Sacy (1758-1838) membantu fondasi-fondasi yang menghantarkan kepada orientalisme modern ${ }^{7}$.

\section{Imajinasi Tentang Timur}

Ekspansi orientalisme ilmiah yang termanifestasikan melalui berkembangnya transliterasi dari bahasa kuno ke bahasa modern, dan kajian serta penelitian yang signifikan di bidang ke-Timur-an, memang menumbuhkan ketertarikan dan bahkan obsesi tentang Timur. Geliat ini diwarnai oleh para pemikir, penulis dan seniman yang menginduk di bawah gerakan Romantisisme di belantika kesusastraan Eropa pada permulaan abad 19.

${ }^{6}$. Nabhan, Faruq Muhammad. Al-Istishraq Ta'rifuhu Madarisihu, Atsaruhu (Rabat: Manshurat alMunadzamah al-Islamiyah li al-Tarbiyah wa al-Ulum wa al-Tsaqafah ISESCO: 2012), hlm.15

7 . Lockman, Zachary. Contending Visions of the Middle East, edisi ke-2 (New York: Cambridge University Press, 2010),hlm.67-68. 
Mereka menolak rasionalisme abad Pencerahan dan bersikukuh menekankan aspek-aspek non-rasio seperti emosi, imajinasi dan intuisi. Beberapa penyair Romantis, novelis, dramatis dan filsuf memandang Timur sebagai "gudang" yang menyembunyikan kebijaksanaan yang bisa menghilangkan dahaga kehausan spiritualitas karena tergerus pandangan materialistik Barat. Nampaknya, dunia Timur memang menjadi tempat yang cocok untuk menghilangkan dahaga imajinasi-imajinasi kaum Romantis.

Timur menyediakan belantara dunia imajiner yang kaya, mitos, dongeng dan perhatian yang besar kepada jiwa, alam, dan kebebasan. Bahkan gaya literatur dan kesusastraan Timur banyak menginspirasi tokoh-tokoh literasi Barat seperti penyair, novelis dan dramatis besar Jerman Johann Wolfgang von Goethe (1749-1832) yang melahirkan karya yang gayanya terinspirasi dari gaya sastra Persia dan Arab. Orang-orang yang hidup di Timur atau Arab digambarkan secara populer meneruskan apa yang terdapat pada karya klasik Seribu Satu Malam, yang pengaruhnya begitu kuat terasa di beberapa tulisan catatan para pelancong, karya sastra dan dongeng-dongeng petualangan untuk orang dewasa dan anak-anak yang bertempat di “Timur" yang aneh, eksotik dan kadang mengancam ${ }^{8}$. Cerita-cerita tentang sihir, Magi, jin, peramal, perempuan dengan kecantikannya, menjadi populer dan diterjemahkan ke dalam bahasa Barat.

Dalam artikelnya yang menarik, Orientalism: The Romantic' Added Dimension, Naji B. Oujian mengatakan bahwa Timur bagi kaum Romantis, merupakan dunia yang penuh eksotisisme, dimulai dengan ketertarikan Barat terhadap Timur. Ketertarikan ini mengindikasikan bahwa bukanlah Barat yang seharusnya menjadi tempat lahirnya peradaban-peradaban kuno dan agama-agama langit, terkhusus Yahud, Kristen dan Islam. Melalui ketertarikan ini, imajinasi Barat mulai dimeriahkan oleh cerita-cerita Kitab Suci dan kekuatan-kekuatan supernatural yang dimiliki Yesus. Fantasi-fantasi tersebut, dibawa ke tanah Barat melalui para cendekiawan dan pendatang Barat ke Timur, lalu kemudian menyerap ke dalam kesadaran Barat dan menghasilkan kekaguman terhadap Timur sebagai Tanah Suci dan bumi eksotis yang dipenuhi oleh keajaiban dan hikmah.

Dalam pengamatan Naji, orientalisme bukan melulu pandangan steorotip negatif Barat tentang Timur-Islam, sebagaimana yang disinyalir bisa difahami dari tulisan Said, melainkan ketertarikan atas Timur yang ikut memeriahkan kesadaran Barat. Bahkan orientalisme, menurut Naji, menjadi fitur esensial yang ada pada puisi-puisi karya kaum

${ }^{8}$ Lockman, Zachary. Contending Visions of the Middle East, edisi ke-2 (New York: Cambridge University Press, 2010), hlm.69. 
Romantis. Naji juga mengutip isu ini dari Maryanne Stevens yang mengatakan: "Satu hal yang benar-benar mempengaruhi pemahaman Barat tentang Timur Dekat ialah kepercayaan bahwa kawasan ini mampu memuaskan kebutuhan Barat akan pengalaman yang eksotik. Eksotisisme berarti pengembaraan artistik terhadap wilayah dan waktu di mana imajinasi yang bebas benar-benar mungkin didapat karena ia terbebas dari aturanaturan klasik yang mengekang."

\section{Orientalisme Romantis}

Ketika masa modern dianggap sebagai Abad Pencerahan, kaum Romantis juga menemani pergerakan tersebut namun dengan kesan yang "agak" antagonistik dengan apa yang digagas oleh orang-orang Pencerahan. Romantisisme merupakan transformasi mendasar pada gaya tulisan, seni, imajinasi, sensitifitas, cita rasa dan ide-ide. Oleh karena itu Romantisisme dikatakan, demikian De Paz, sebagai "anak kecil yang membangkang"9. Timur nampaknya menyediakan apa yang menjadi obesesi kaum Romantik. Semesta Timur yang dipenuhi hal-hal yang melampaui jangkauan rasio dan memberi kesempatan untuk imajinasi terbang lebih bebas membuat citra Timur begitu menarik dan dampaknya signifikan dalam membentuk kesadaran Barat.

Salah satu tokoh Romantis yang menaruh perhatian terhadap Timur adalah Lord Byron, ia pergi ke Timur karena Timur memiliki kekuatan, bijak, penuh sensasi dan pada waktu yang sama, memiliki kesan primitif yang menarik dan indah. Bagi Byron, sebagaimana para penyair Romantis lainnya, hasrat yang kuat merupakan esensi dan kehidupan yang puitis. Di Timur, ia mampu menikmati kehidupannya dalam kondisi yang jauh dari kehidupan formal yang kaku di Inggris. Naji mengutip, "Seperti para penulis Romantis Prancis belakangan Chaeaubriand, Lamartine, Flaubert dan de Nerval, perjalanan Byron ke Timur merupakan ziarah pribadi menuju istirahat yang eksotik bagi pikirannya sendiri untuk mengungkap misteri keberadaannya sendiri."

Tapi lebih dari itu, lanjut Naji, Byron berkontemplasi terhadap beberapa aspek yang menjadi gairah pandangan kaum Romantis, yaitu pencarian manusia terhadap identitasnya yang sejadi di dalam dunia yang penuh dengan konflik dan hal-hal kontradiktif. Apapun di dunia ini adalah hal yang mungkin, di mana setiap momen akan membawa pengalaman asli, dan setiap pengalaman akan mengantarkan manusia menuju identitas sejatinya. Dari titik ini, Orientalisme menarik Byron menuju dunia yang memiliki kesadaran lebih tinggi

${ }^{9}$ Brown, Marshall (ed.) The Cambridge History of Literary Criticism vol.5 Romanticism (New York: Cambridge University Press, 2007).hlm. 31. 
dan menstimulus puisi-puisinya yang brilian untuk menambah dimensi tersebut yang ia cari dalam kehidupan pribadinya, juga karya-karyanya.

Jika ditarik kesimpulan sederhana, maka Orientalisme bagi kaum Romantis bukanlah semacam pemisahan antara mana "Barat" dan mana "Timur". Timur dipandang kaum Romantis lebih sebagai representasi bagi emosi dan kebebasan. Timur telah memberi kepada para penulis Romantis sebuah kesempatan untuk membobol bentuk-bentuk imajinasi terbatas yang ada pada masa sebelumnya. Sikap Barat terhadap Timur seperti inilah yang memotivasi para sarjana Barat untuk memperdalam penelitian mereka terhadap budaya yang terus menerus menelurkan hal-hal yang baru.

\section{E. Kesimpulan}

Pandangan kaum Romantis terhadap Timur barangkali agak kontras dari apa yang diimajinasikan oleh Said. Apa yang disebut Said sebagai "trauma yang tidak berkesudahan" bukanlah disebabkan oleh Islam dan Kristen, melainkan secara langsung disebabkan oleh adanya kekuatan yang bersitegang antara Timur-Islam dan Barat-Kristen. Sikap antagonistik antar kedua agama itu lebih didominansi oleh faktor politis, peperangan, persaingan dan dendam kesumat. Barat merasa terganggu oleh "ekspansi kekuatan" yang berhasil dilakukan oleh orang-orang muslim Seljuk, Mongol dan imperium besar Turki Utsmaniyah. Dapat dikatakan bahwa konflik sebenarnya bukan antara dua agama seperti yang ingin dikampanyekan oleh pasukan salib. Konflik sejatinya terjadi antara "kekuatan" dua dunia, Timur dan Barat.

Orientalisme kaum Romantis yang dibalut oleh kekaguman dan eksotisme terhadap Timur barangkali menjadi pengertian lain tentang makna orientalisme itu sendiri, yang tentunya berbeda dari makna orientalisme yang ingin dibongkar oleh Said. Lagipula, apabila kita melihat lebih dekat pendekatan Romantis ini, kajian ke-Timur-an tidak saja terbatas pada studi tentang Islam. faktanya, kajian tentang Kitab Suci menjadi terintegrasi dan bagian yang ada pada Orientalisme. Para murid teologi Kristen seperti Bede, Shelling, Hegel dan lainnya merupakan sarjana-sarjana Oriental karena mereka tekun mempelajari cerita Kitab Suci dari Timur.

Apa yang disebut-sebut bahwa orientalisme adalah propaganda Barat dan menyimpan agenda politik di dalamnya barangkali memang benar. Karya-karya Barat yang sengaja melakukan distorsi terhada gambaran islam, Timur dan budayanya, memang tidak diragukan kehadirannya. Akan tetapi, gerakan ini tidak bisa dikatakan sebagai "Orientalisme," melainkan "Orientalisme Palsu" (False Orientalism). Dapat disimpulkan, bahwa Orientalisme lebih baik dipandang sebagai gerakan yang dinamis, sebagaimana 
bahasa juga mendapati dirinya bersifat dinamis dan berubah sepanjang waktu. Materimateri tentang Timur banyak bermunculan dalam karya-karya sastra yang dihasilkan oleh para wisatawan dan sarjana independen, yang membebaskan diri mereka dari agenda politik dan sinisme agama terhadap Timur. Fakta seperti ini juga yang sebenarnya disadari oleh Said sendiri, bahwa ada beberapa orientalis yang secara baik mampu mempresentasikan Timur dengan otentik dan simpatik.

\section{F. Daftar Pustaka}

Brown, Marshall (ed.) The Cambridge History of Literary Criticism vol.5 Romanticism (New York: Cambridge University Press, 2007).

Kalmar, Ivan. Early Orientalism Imagined Islam and The Notion of Sublime Power (New York: Routledge, 2012)

Lockman, Zachary. Contending Visions of the Middle East, edisi ke-2 (New York: Cambridge University Press, 2010).

Nabhan, Faruq Muhammad. Al-Istishraq Ta'rifuhu Madarisihu, Atsaruhu (Rabat: Manshurat al-Munadzamah al-Islamiyah li al-Tarbiyah wa al-Ulum wa al-Tsaqafah ISESCO: 2012)

Orientalism: The Romantic's Added Dimension; or Edward Said Refuted, artikel oleh Naji B. Oueijan (Universitas Notre Dame, Zouk Mikayel, Lebanon. Diakses dari http://webdoc.sub.gwdg.de/edoc/ia/eese/artic20/naji/3_2000.html pada 9 Januari $\underline{2015}$.

Said, Edward. Orientalism, terj. Achmad Fawaid (Yogyakarta: Pustaka Pelajar, 2010) 